\title{
Pengembangan Buku Ajar Sejarah Fisika Berbasis ICT
}

\author{
${ }^{1}$ Lia Angraeni, ${ }^{2}$ Boisandi, ${ }^{3}$ Matsun \\ ${ }^{1,2,3}$ IKIP PGRI Pontianak, Jl. Ampera No. 88A Pontianak, Kalimantan Barat, 78117 \\ Email Korespondensi: $\underline{\text { lia060787@ gmail.com }}$
}

\begin{tabular}{|c|c|}
\hline Article Info & Abstract \\
\hline $\begin{array}{l}\text { Article History } \\
\text { Received: November } \\
\text { Revised: December } \\
\text { Published: December }\end{array}$ & \multirow{2}{*}{$\begin{array}{l}\text { This study aims to determine: (1) The feasibility of ICT-based Physics History } \\
\text { textbooks according to material experts, (2) The feasibility of ICT-based } \\
\text { Physics History textbooks according to media experts. The research method } \\
\text { used is R\&D with reference to the 4-D model (four D model). The 4-D model } \\
\text { consists of the define, design, development and disseminate stages. The } \\
\text { development of ICT-based Physics History textbooks is the development of } \\
\text { textbooks that help students in building information (knowledge) in } \\
\text { understanding concepts through ICT in e-books in Physics History courses } \\
\text { delivered. This is in accordance with KKNI curriculum planning, where the } \\
\text { implementation of learning in the classroom is carried out with the Scientific } \\
\text { Approach approach which includes observing, questioning, experimenting, } \\
\text { associating (discussion), and networking (presentation). The results of the } \\
\text { study are as follows: (1) ICT-Based Physics History Teaching books that have } \\
\text { been validated by material experts with appropriate performance with an } \\
\text { average value of 78, (2) ICT-Based Physics History Teaching books that have } \\
\text { been validated by media experts with expertise suitable for use with an average } \\
\text { rating of } 80 \text {. }\end{array}$} \\
\hline $\begin{array}{l}\text { Keywords } \\
\text { Textbooks, History of } \\
\text { Physics, ICT }\end{array}$ & \\
\hline Informasi Artikel & Abstrak \\
\hline $\begin{array}{l}\text { Sejarah Artikel } \\
\text { Diterima: November } \\
\text { Direvisi: November } \\
\text { Dipublikasi: November } \\
\text { Kata kunci } \\
\text { Buku ajar, Sejarah Fisika, } \\
\text { ICT }\end{array}$ & $\begin{array}{l}\text { Penelitian ini bertujuan untuk mengetahui: (1) kelayakan buku ajar Sejarah } \\
\text { Fisika berbasis ICT menurut ahli materi, (2) kelayakan buku ajar Sejarah Fisika } \\
\text { berbasis ICT menurut ahli media. Metode penelitian yang digunakan adalah } \\
\text { R\&D dengan mengacu model 4-D (four D model). Model 4-D terdiri dari tahap } \\
\text { define, design, development dan disseminate. Pengembangan buku ajar Sejarah } \\
\text { Fisika berbasis ICT merupakan pengembangan buku ajar yang membantu } \\
\text { mahasiswa dalam membangun informasi (pengetahuan) dalam memahami } \\
\text { konsep melalui ICT pada e-book dalam mata kuliah Sejarah Fisika yang } \\
\text { disampaikan. Hal ini sesuai dengan perencanaan kurikulum KKNI, dimana } \\
\text { pelaksanaan pembelajaran di dalam kelas dilaksanakan dengan pendekatan } \\
\text { Scientific Approach yang meliputi observing (mengamati), questioning } \\
\text { (bertanya), experimenting (eksprimen), associating (diskusi), dan networking } \\
\text { (presentasi). Hasil penelitian sebagai berikut: (1) buku Ajar Sejarah Fisika } \\
\text { Berbasis ICT yang telah di validasi oleh ahli materi dengan keteria layak } \\
\text { digunakan dengan nilai rata-rata 78, (2) buku Ajar Sejarah Fisika Berbasis ICT } \\
\text { yang telah di validasi oleh ahli media dengan keteria layak digunakan dengan } \\
\text { nilai rata-rata } 80 \text {. }\end{array}$ \\
\hline
\end{tabular}

Sitasi: Anggraeni, L., Boisandi, \& Matsun. Pengembangan Buku Ajar Sejarah Fisika Berbasis ICT. Kappa Journal, Pendidikan Fisika, FMIPA, Universitas Hamzanwadi. 3 (2), 126-133

\section{PENDAHULUAN}

Sains berkaitan dengan cara mencari tahu tentang alam secara sistematis, sehingga sains bukan hanya penguasaan sekumpulan pengetahuan yang berupa fakta-fakta, konsepkonsep atau prinsip-prinsip saja, tapi juga merupakan suatu proses penemuan dan pemahaman akan konsep-konsep yang ditentukan. Sebagai salah satu bidang sains, Fisika diadakan dalam rangka mengembangkan kemampuan menyelesaikan masalah untuk memahami konsep-konsep yang ditemukan dalam peristiwa sekitar, baik secara kualitatif 
maupun secara kuantitatif. Tapi pada kenyataannya proses pembelajaran fisika yang terjadi belum sesuai dengan fungsi dan tujuan pembelajaran fisika.

Perguruan Tinggi tempat berlangsungnya proses pembelajaran menuntut setiap dosen untuk dapat memberikan proses pembelajaran yang menarik bagi mahasiswa di kelas, sehingga mahasiswa juga dapat mengikuti proses pembelajaran dengan efektif dan bermanfaat. Dosen dituntut untuk dapat berperan aktif lebih luas menyangkut upaya untuk menciptakan kehidupan masyarakat yang lebih baik dengan adanya perkembangan sains teknologi lingkungan dan masyarakat yang sedang berlangsung keterkaitanya dengan dunia pendidikan. Hal ini menunjukkan bahwa lembaga kependidikan khususnya pada jenjang perguruan tinggi diharapkan dapat merancang sendiri perangkat pembelajaran yang diperlukan untuk keberlangsungan proses pembelajaran.

Trianto (2007:89) menyatakan bahwa orang hanya mampu mengingat $20 \%$ dari yang dilihat dan 30\% dari yang didengar. Namun, mereka mengingat 50\% dari yang dilihat sekaligus didengar dan sebanyak $80 \%$ dari yang dilihat, didengar, dan yang dilakukan sekaligus. Dengan demikian, buku ajar menjadi perangkat ampuh untuk proses pengajaran dan pendidikan. Adapun manfaat yang didapat menurut Winkel W.S (2009) adalah proses pembelajaran menjadi menarik, lebih interaktif, jumlah waktu mengajar (ceramah) dapat dikurangi, kualitas belajar mahasiswa dapat lebih termotivasi dan terdongkrak serta belajar mengajar dapat dilakukan dimana saja dan kapan saja (sangat fleksibel), serta sikap dan perhatian belajar mahasiswa dapat ditingkatkan dan dipusatkan. Buku ajar juga dapat memungkinkan siswa belajar secara mandiri sehingga pembelajaran tidak hanya dilaksanakan di sekolah tetapi dapat dilaksanakan di luar sekolah dan di laboratorium.

Untuk mengatasi masalah pembelajaran maka dosen harus dapat mengembangkan buku ajar yang inovatif dan tepat. Ketidaksesuaian dalam mengembangkan buku ajar dengan karakteristik mahasiswa dan karakteristik mata pelajaran akan membuat pembelajaran tidak bermakna dan mahasiswa sulit memahami materi, yang berakibat pada kurangnya keaktifan mahasiswa serta prestasi belajar rendah.

Pengembangan buku ajar yang baik, jika tidak diimbangi dengan pelaksanaan pembelajaran di dalam kelas, tentunya tidak akan membantu mahasiswa dalam mencapai kompetensi yang ingin dicapai. Buku ajar Sejarah Fisika berbasis ICT merupakan suatu pengembangan buku ajar yang dikaitkan strategi pelaksanaan pembelajaran dikelas yang aktif, inofatif, efektif dan menarik. Pengembangan buku ajar Sejarah Fisika berbasis ICT merupakan pengembangan buku ajar yang membantu mahasiswa dalam membangun informasi (pengetahuan) dalam memahami konsep melalui ICT pada e-book dalam mata kuliah Sejarah Fisika yang disampaikan. Hal ini sesuai dengan perencanaan kurikulum KKNI, dimana pelaksanaan pembelajaran di dalam kelas dilaksanakan dengan pendekatan Scientific Approach yang meliputi observing (mengamati), questioning (bertanya), experimenting (eksprimen), associating (diskusi), dan networking (presentasi). Dengan demikian, perlu dilakukan penelitian pengembangan buku ajar Sejarah Fisika berbasis ICT.

\section{METODE}

Metode penelitian dan pengembangan atau Research and Development (R\&D) adalah metode penelitian yang digunakan untuk menghasilkan produk tertentu dengan menguji keefektifan produk tersebut (Sugiono, 2010). Penelitian dan dan pengembangan dilakukan dengan tahaptahap prosedural yaitu tahap perencanaan, pelaksaanaan, dan penilaian produk. Model pengembangan yang dilakukan mengikuti beberapa tahapan pengembangan media.

Prosedur dalam penelitian ini menggunakan pengembangan perangkat model 4-D (four D model) yang dikemukakan oleh Thiagarajan dan Semmel (1974) dalam Trianto 
(2010). Model ini terdiri dari 4 tahap pengembangan, yaitu Define, Design, Develop, and Disseminate.

\section{HASIL DAN PEMBAHASAN}

Data yang diperoleh terdiri dari data hasil validasi produk oleh validator ahli materi dan ahli media., bahasa dan gambar, penyajian, serta kegrafisan dan data hasil uji coba mahasiswa pada aspek materi, bahasa dan gambar, penyajian, serta tampilan buku. Berikut ini akan disajikan data hasil penilaian kelayakan buku ajar dari 2 dosen ahli. Data hasil uji coba dari mahasiswa akan disajikan secara umum yang diambil dari 5 mahasiswa semester VII.

\section{Data Hasil Validasi Ahli}

Dosen ahli menilai aspek materi, bahasa dan gambar, penyajian, serta kagrafisan. Data hasil validasi oleh dosen ahli menunjukkan bahwa jumlah skor keseluruhan untuk setiap validator yakni ahli I dan ahli II masing- masing memberikan nilai 78 dan 80. Rincian penilaian buku ajar menurut ahli dapat dilihat pada Lampiran 4. Kriteria penilaian buku ajar menurut ahli ditunjukkan pada Tabel 4.1.

Tabel 1. Kriteria Penilaian Buku Ajar oleh Ahli

\begin{tabular}{|c|c|c|c|c|}
\hline No & Validator & $\begin{array}{l}\text { Skor rata- } \\
\text { rata }\end{array}$ & Nilai & Kriteria \\
\hline 1 & Ahli Materi & 78 & B & Layak \\
\hline 2 & Ahli Media & 80 & B & Layak \\
\hline Rata-rata & & 79 & B & Layak \\
\hline
\end{tabular}

Berdasarkan hasil kuantisasi angket dari ahli memberikan penilaian bahwa buku ajar memenuhi kriteria baik. Hal tersebut terlihat pada Tabel 1. Artinya dosen ahli yang memvalidasi memberikan skor yang masuk ke dalam kriteria baik, sehingga dapat dikatakan bahwa buku ajar sejarah fisika berbasis ICT yang telah dikembangkan telah siap untuk uji coba sesuai dengan saran dan komentar yang dijadikan revisi.

Hasil penilaian buku ajar oleh ahli di dukung oleh data yang diperoleh dari aspek materi, aspek bahasa dan media (gambar, aspek penyajian, serta aspek kegrafisan) yang diuraikan sebagai berikut :

a. Aspek Materi

Data hasil penilaian buku ajar sejarah fisika berbasis ICT menunjukkan bahwa jumlah skor untuk ahli materi dengan skor rata-rata 78 (Tabel 1). Distribusi frekuensi kriteria penilaian buku ajar untuk aspek materi menurut ahli data. Berdasarkan hasil data tersebut, ahli menilai layak mengenai aspek materi buku ajar sejarah fisika berbasis ICT yang dikembangkan. Data hasil penilaian buku ajar sejarah fisika berbasis ICT merupakan rangkuman data yang berasal dari indikator pada aspek materi tersebut.

Deskripsi data menunjukkan sebaran penilaian buku ajar sejarah fisika berbasis ICT mengenai aspek kelayakan materi pada setiap indikator. Tujuh indikator mengenai kesesuaian materi dengan silabus dan RPP, kesesuaian materi dengan KI, kesesuaian materi dengan tujuan pembelajaran, kebenaran materi, materi yang disajikan menuntun mahasiswa berfikir kreatif, materi yang disajikan menuntun mahasiswa berfikir inovatif, dan materi yang disajikan menuntun mahasiswa mengaplikasikan teori dalam eksprimen. Indikator kesesuaian materi dengan $\mathrm{KD}$ dan materi yang disajikan dalam buku ajar menimbulkan suasana menyenangkan dan menarik untuk dibaca mendapatkan skor 3 sebanyak $50 \%$ dan skor 4 sebanyak $50 \%$. Sedangkan pada indikator kesembilan yaitu materi yang disajikan dalam buku ajar mudah dipahami mendapatkan skor 4 sebanyak $100 \%$.

Data tersebut menunjukkan bahwa pada setiap indikator dalam aspek kelayakan materi memiliki skor yang mencakup kriteria baik (skor 3) dan sangat baik (skor 4). Adapun saran dan komentar yang sudah adamenjadi referensi revisi yang akan diuraikan 
dalam pembahasan.

b. Aspek Media

Data hasil penilaian buku ajar sejarah fisika berbasis ICT menunjukkan bahwa jumlah skor rata-rata validator media yaitu 52 (Tabel 1). Distribusi kriteria penilaian buku ajar untuk aspek bahasa menurut ahli media. Berdasarkan hasil data tersebut, ahli menilai layak mengenai aspek media dalam buku ajar sejarah fisika berbasis ICT yang dikembangkan. Data hasil penilaian buku ajar sejarah fisika berbasis ICT merupakan rangkuman data yang berasal dari 14 indikator pada aspek media

Deskripsi data menunjukkan sebaran penilaian buku ajar sejarah fisika berbasis ICT mengenai aspek kelayakan media pada setiap indikator. Empat belas indikator mengenai penggunaan jenis huruf, pemilihan ukuran huruf, pemilihan warna huruf, teknik penulisan/tatatulis, penggunaan warna, efek cahaya pafa warna, pemilihan warna, penggunaan gambar, kesesuaian animasi, desain background, tataletak, fleksibilitas tatalekat, respon yang diberikan, dan hubungan timbal balik. masing-masing memperoleh skor 3 (Baik) sebesar $28 \%$ pada indikator pemilihan warna, teknik penulisan, penggunaan warna, dan fleksibelitas tataletak. Indikator mendapatkan skor 4 (sangat Baik) sebanyak $72 \%$. Data tersebut menunjukkan bahwa pada setiap indikator dalam aspek kelayakan media memiliki skor yang mencakup kriteria baik (skor 3) dan sangat baik (skor 4). Adapun saran dan komentar yang sudah ada menjadi referensi revisi yang akan diuraikan dalam pembahasan.

\section{Data Hasil Uji Coba Lapangan}

Uji coba lapangan terbagi dalam dua tahap, yaitu uji coba awal dan uji coba utama. Hasil uji coba awal dilakukan dengan lima orang mahasiswa dan pada uji coba utama menggunakan 20 mahasiswa. Uji coba dilakukan kepada mahasiswa semester VII program studi pendidikan fisika kelas A pagi. Hasil uji coba menunjukkan bahwa jumlah skor keseluruhan untuk setiap siswa yakni sebagai berikut:

a. Uji Coba Awal

Tabel 2. Hasil Uji Coba Awal Mahasiswa

\begin{tabular}{lllll}
\hline No & Responden & Skor & Nilai & Kriteria \\
\hline 1 & 1 & 79 & B & Layak \\
2 & 2 & 77 & B & Layak \\
3 & 3 & 78 & B & Layak \\
4 & 4 & 76 & B & Layak \\
5 & 5 & 78 & B & Layak \\
\hline Rata-rata & & 77.6 & B & Layak \\
\hline
\end{tabular}

Hasil uji coba awal dapat diketahui dari e valuas i angket yang diberikan kepada 5 orang mahasiswa semester V kelas A pagi. Berdasarkan tabel 2 data hasil uji coba awal menunjukkan bahwa dari jumlah skor keseluruhan diperoleh skor tertinggi 47 (responden 2 ) dan skor terendah 38 (responden 3). Dengan rata -rata 41 dengan nilai B keteria Baik.

\section{b. Uji Coba Utama}

Hasil uji coba utama dapat diketahui dari angket yang diberikan kepada 20 mahasiswa kelas A Pagi semester VII program studi pendidikan Fisika. Hasil penilaian total pada uji coba utama ditunjukkan pada Tabel 3. Berdasarkan analisis data hasil uji coba utama menunjukkan bahwa dari jumlah skor keseluruhan diperoleh skor tertinggi 45 (responden 5, 6, 7, 9, 11, $12,13,15,18,19,20$ ) dan skor terendah 26 (responden 16). Dengan rata-rata skor 43,7 dengan kreteria baik. 
Tabel 3. Hasil Uji Coba Awal Mahasiswa

\begin{tabular}{lllll}
\hline No & Responden & Skor & Nilai & Kriteria \\
\hline 1 & $1,2,3,4$ & 79 & B & Layak \\
2 & $5,6,7,9,11,12,13,15,18,19,20$ & 83 & B & $\begin{array}{l}\text { Sangat } \\
\text { layak }\end{array}$ \\
3 & 8,14 & & & Layak \\
4 & $10,16,17$ & 78 & B & Layak \\
5 & 16 & 77 & B & Cukup \\
& & 76 & C & \\
\hline $\begin{array}{l}\text { Rata- } \\
\text { rata }\end{array}$ & & 78.6 & B & Layak \\
\hline
\end{tabular}

Penelitian Pengembangan Buku Ajar Sejarah Fisika Berbasis ICT ini dilakukan dimulai dari tahap observasi penelitian (research) dan pengembangan (development) dan pembuatan desain. Berdasarkan tujuan penelitian yaitu untuk mengetahui kelayakan Buku Ajar Sejarah Fisika Berbasis ICT menurut ahli materi dan untuk mengetahui kelayakan Buku Ajar Sejarah Fisika Berbasis ICT menurut ahli media. Untuk penilaian dari ahli materi dan ahli media, yang digunakan sebagai acuan layak atau tidaknya Buku Ajar Sejarah Fisika Berbasis ICT dengan memberikan angket kelayakan kepada ahli materi dan media. Secara ringkas data hasil penelitian dan pengembangan Buku Ajar Sejarah Fisika Berbasis ICT adalah sebagai berikut:

\section{Kelayakan Media Pembelajaran Menurut Ahli Materi}

Sebelum produk di gunakan oleh dosen, produk di validasi terlebih dahulu oleh ahli materi. Validasi ini dilakukan agar produk buku ajar yang dikembangkan mendapatkan jaminan bahwa produk awal yang dikembangkan layak digunakan oleh mahasiswa. Selain itu validasi ahli materi berguna untuk mengantisipasi kesalahan materi, kekurangan materi, dan antisipasi saat penggunaan buku ajar di sekolah. Validasi ahli materi dilakukan agar produk yang dikembangkan tidak mengalami banyak kesalahan dan sesuai dengan kebutuhan mahasiswa. Setelah desain produk diselesaikan, desain produk tersebut diserahkan kepada validator untuk di validasi dan dinilai kelayakannya.

Tabel 4. Nilai Tiap Aspek Ahli Materi

\begin{tabular}{llll}
\hline Validator & Aspek & Nilai & Keteria \\
\hline \multirow{4}{*}{ Ahli Materi } & Isi & 78 & \\
& Penyajian & 76 & \\
& Bahasa & 80 & \\
Rata-rata & ICT & 78 & Layak \\
\hline
\end{tabular}

Validator ahli materi dalam validasi Buku Ajar Sejarah Fisika Berbasis ICT yaitu 1 orang dosen Program Studi Pendidikan Fisika yang ahli dibidang materi. Validasi ahli materi dilakukan dengan memberikan buku ajar beserta lembar penilaian. Lembar penilaian berupa lembar validasi dengan 54 butir soal tentang aspek kelayakan isi, aspek kelayakan penyajian, penilaian bahasa, dan penilaian model ICT.

Proses penilaian terhadap ahli materi dilakukan satu kali validasi ahli materi. Setelah dilakukan validasi pada produk dapat diketahui terdapat kekurangan serta perlu dilakukan perbaikan terhadap produk Buku Ajar Sejarah Fisika Berbasis ICT yang telah dikembangkan. Dapat dilihat pada tabel 1 hasil penilaian ahli materi berdasarkan tiap aspek yang di gunakan. Dari perhitungan table 1 pada ke 4 aspek diatas dapat disimpulkan bahwa berdasarkan aspek Materi mendapatkan rata-rata nilai 78 dengan kriteria layak, aspek isi mendapatkan rata-rata 
nilai 78, aspek penyajian mendapatkan nilai rata-rata 76 , aspek bahasa 80 dan ICT mendapatkan nilai rata-rata 78. Nilai untuk tiap aspek dapat dilihat pada table $1 \mathrm{di}$ atas.

Berdasarkan data diatas Buku Ajar Sejarah Fisika Berbasis ICT dikatakatan sangat layak dari segi aspek isi, penyajian, bahasa, dan eksprimen. Sehingga Buku Ajar Sejarah Fisika Berbasis ICT layak digunakan dalam proses pembelajaran. Setelah memperoleh hasil penelitian ahli materi pada tahap pertama tersebut, selanjutnya di lakukan revisi pada tahap pertama agar produk media yang di kembangkan lebih baik dari sebelumnya. Perbaikan di lakukan berdasarkan penilaian dan saran dari ahli materi. Bagian-bagian perbaikan dijelaskan sebagai berikut. Berikut hasil validasi oleh ahli materi dengan komentar dan saran. Berdasarkan validasi oleh ahli materi untuk b Buku Ajar Sejarah Fisika Berbasis ICT ada perbaikan pada bagian materi yang telah di buat. Setelah bagian materi di perbaiki maka materi dikatakan layak digunakan. Berikut hasil perbaikan yang dilakukan.

Tabel 5. Hasil Revisi Ahli Materi

\begin{tabular}{|c|c|c|}
\hline No. & Sebelum Revisi & Sesudah Revisi \\
\hline 1 & $\begin{array}{l}\text { Berdasarkan penilaian validator sebaiknya contoh } \\
\text { soal dibuat lebih akurat sesauai dengan indikator }\end{array}$ & $\begin{array}{l}\text { Memperbaiki soal lebih akurat } \\
\text { lagi }\end{array}$ \\
\hline 2 & $\begin{array}{l}\text { Berdasarkan penilaian validator bahwa buku ajar } \\
\text { yang dikembangkan acuan pustakanya masih } \\
\text { belum akurat }\end{array}$ & $\begin{array}{l}\text { Mencari acuan pustaka untuk } \\
\text { pengembngan buku ajar agar } \\
\text { relevan }\end{array}$ \\
\hline 3 & $\begin{array}{l}\text { Berdasarkan penilaian validator bahwa buku ajar } \\
\text { yang dikembangkan perlu menambahkan gambar } \\
\text { dan ilustrasi aktual }\end{array}$ & $\begin{array}{l}\text { Menambahkan gambar dan } \\
\text { ilustrasi aktual sesuai dengan } \\
\text { jenjang pendidikan siswa. }\end{array}$ \\
\hline 4 & $\begin{array}{l}\text { Berdasarkan penilaian validator bahwa tampilan } \\
\text { buku ajar yang dikembangkan masih kurang } \\
\text { menarik }\end{array}$ & $\begin{array}{l}\text { Membuat tampilan buku ajar } \\
\text { lebih menarik lagi. }\end{array}$ \\
\hline 5 & $\begin{array}{l}\text { Berdasarkan penilaian validator bahwa buku ajar } \\
\text { yang dikembangkan struktur kalimat dan } \\
\text { keefektifan kalimat masih blum sesuai dengan } \\
\text { EYD. }\end{array}$ & $\begin{array}{l}\text { Menyesuaikan struktur kalimat } \\
\text { dengan EYD. }\end{array}$ \\
\hline
\end{tabular}

\section{Kelayakan Media Pembelajaran Menurut Ahli Media}

Sebelum produk di uji cobakan ke lapangan, produk di validasi terlebih dahulu oleh ahli media. Pada tahap validasi desain yang dilakukan adalah dengan menyerahkan dan mempresentasikan desain produk awal untuk di validasi oleh ahli. Validasi media dilakukan penilaian berdasarkan sudut pandang media yang tertuang di dalam Buku Ajar Sejarah Fisika Berbasis ICT. Validasi ini di lakukan agar produk b Buku Ajar Sejarah Fisika Berbasis ICT yang di kembangkan dapat di katakan layak dan dapat di ujicobakan terhadap mahasiswa. Selain itu validasi ahli berguna untuk mengantisipasi kesalahan materi, kekurangan materi, antisipasi saat di ujicoba di lapangan dan lain-lain. Selain desain produk di selesaikan, desain produk tersebut dapat di serahkan kepada validator untuk di validasi dan di nilai kelayakannya.

Validator ahli media dalam validasi media pada Buku Ajar Sejarah Fisika Berbasis ICT yaitu 1 orang dosen Program Studi Pendidikan fisika . Validasi ahli media di lakukan dengan memberikan produk beserta lembar penilaian. Lembar penilaian berupa lembar validasi dengan 31 butir penilaian tentang ukuran modul, desain sampul modul, dan desain isi sampul. Proses penilaian terhadap ahli media dilakukan satu kali validasi ahli media. Setelah dilakukan validasi pada buku ajar dapat diketahui tidak ada revisi yang terlalu signifikan pada 
Buku Ajar Sejarah Fisika Berbasis ICT. Berikut tabel 4.4 hasil enilaian ahli media berdasarkan tiap aspek yang di gunakan.

Tabel 6. Perolehan Aspek Lembar Validasi Media

\begin{tabular}{clcc}
\hline \multicolumn{1}{c}{ Validator } & \multicolumn{1}{c}{ Aspek } & Nilai & Keteria \\
\hline \multirow{3}{*}{ Ahli Media } & Ukuran Modul & 81 & \\
& Desain Sampul Modul & 80 & \\
& Desain Isi Modul & 79 & \\
\hline Rata-rata & & 80 & Layak \\
\hline
\end{tabular}

Dari perhitungan tabel 6 pada ke 3 aspek diatas dapat disimpulkan bahwa berdasarkan aspek Media mendapatkan rata-rata nilai 80 dengan kriteria layak, aspek ukuran modul mendapatkan nilai rata-rata skor 81 , aspek desain sampul modul mendapatkan nilai rata-rata 79, dan aspek desain isi modul mendapatkan nilai dengan rata-rata 80. Berdasarkan data diatas bahwa Buku Ajar Sejarah Fisika Berbasis ICT dikatakatan layak dari segi aspek ukuran modul, desain sampul modul, dan desain isi modul. Sehingga sejarah fisika berbasis ICT dikatakan layak digunakan dalam proses pembelajaran. Berdasarkan validasi oleh ahli madia untuk Buku Ajar Sejarah Fisika Berbasis ICT ada perbaikan pada bagian tampilan yang telah di buat. Setelah bagian media di perbaiki maka buku ajar dikatakan layak digunakan. Berikut hasil perbaikan yang dilakukan.

Berdasarkan penelitian yang berjudul Pengembangan Buku Ajar Sejarah Fisika Berbasis ICT, telah dikembangkan menurut langkah-langkah Four $D$ dan menggunakan teknik analisis data deskriptif kualitatif yaitu data reduction, data display dan data conclusion (Miles dan Hubermen dalam Sugiyono, 2016: 369) dapat dikemukakan bahwa pengembangan Buku Ajar Sejarah Fisika Berbasis ICT telah dilaksanakan sesuai dengan metode yang digunakan. Berdasarkan hasil analisis data pada validasi ahli materi, diperoleh skor rata-rata 78. Rata-rata skor penilaian ahli materi yang diperoleh produk Buku Ajar Sejarah Fisika Berbasis ICT yang dikembangkan tersebut termasuk dalam kriteria layak. Sedangkan hasil analisis data ahli media, diperoleh skor rata-rata 80 dengan kategori layak. Produk Buku Ajar Sejarah Fisika Berbasis ICT yang telah mendapat rekomendasi layak dari ahli materi maupun ahli media sudah memenuhi syarat untuk di gunakan di skelas. Setelah dilakukan validasi dilakukan proses revisi terhadap produk Buku Ajar Sejarah Fisika Berbasis ICT. Selama validasi dilaksanakan tidak ditemukan kendala yang berarti sehingga mengharuskan revisi. Hal ini sejalan dengan pendapat Sugiyono (2015: 426) bahwa revisi produk dilakukan apabila terdapat kekurangan dan kelemahan.

Buku Ajar Sejarah Fisika Berbasis ICT merupakan salah satu media pembelajaran. Edgar Dale memandang bahwa nilai buku ajar dalam pembelajaran diklasifikasikan berdasarkan nilai pengalaman belajar. Tingkat pengalaman yang paling tinggi nilainya adalah pengalaman yang paling konkrit. Sedangkan yang paling rendah adalah yang paling abstrak. Hal ini sebagaimana diungkapkan oleh Edgar Dale. Ia menyatakan bahwa hasil belajar seseorang diperoleh mulai dari pengalaman langsung (konkrit) berdasarkan kenyataan yang ada di lingkungan hidupnya, kemudian melalui benda-benda tiruan, dan selanjutnya sampai kepada lambang-lambang verbal (abstrak). Untuk kondisi seperti inilah kehadiran buku ajar menjadi sangat signifikan bagi terciptanya proses dan hasil pembelajaran yang optimal. Dalam posisinya ini, buku ajar diharapkan dapat merangsang keterlibatan berbagai alat indera atau dimaksimalkan bagi seluruh alat indera pembelajar. Tingkat pengalaman yang paling tinggi adalah direct experience, pengalaman yang diperoleh dari hasil kontak langsung dengan lingkungan objek, binatang, manusia dan sebagainya, dengan cara melakukan perbuatan langsung. Tingkatan kedua adalah pengalaman yang diperoleh dari kontak melalui model, benda tiruan atau simulasi (contrived experience). Pengalaman tingkat berikut dan 
seterusnya adalah dramatized experience, yaitu pengalaman yang diperoleh melalui permainan (permainan pembelajaran), sandiwara boneka, permainan peranan dan drama sosial atau psikologis. Demonstrasi diperoleh melalui pertunjukan. Study trif melalui karya wisata. Exhibition melalui pameran. Educational television melalui televisi pendidikan. Motion pictures melalui gambar atau film hidup, atau bisokop. Strill pictures melalui gambar mati, slide atau fotografi. Radio and recording melalui siaran radio atau rekaman suara (audio recording). Visual symbol melalui symbol yang dapat dilihat seperti grafik, bagan atau diagram. Dan verbal symbol diperoleh melalui penuturan dengan kata-kata. Jadi pengalaman nomor satu adalah yang paling tinggi nilainya dan paling konkrit dan nomor terakhir paling rendah dan paling abstrak (Sumiati dan Asra, 2008: 175).

\section{KESIMPULAN}

Berdasarkan kajian teori, data hasil penelitian dan pembahasan yang mengacu pada perumusan masalah yang telah diuraikan pada bab sebelumnya, dapat disimpulkan sebagai berikut: (1) Buku Ajar Sejarah Fisika Berbasis ICT yang telah di validasi oleh ahli materi dengan keteria layak digunakan dengan nilai rata-rata 78, (2) Buku Ajar Sejarah Fisika Berbasis ICT yang telah di validasi oleh ahli media dengan keteria layak digunakan dengan nilai rata-rata 80 .

\section{SARAN}

Berdasrkan kesimpulan dalam penelitian ini, maka peneliti mengajukan saran-saran sebagai berikut: (1) hasil penelitian ini dapat digunakan sebagai acuan untuk penelitian berikutnya yang sejenis dengan mata pelajaran yang berbeda, (2) pembelajaran menggunakan Buku Ajar Sejarah Fisika Berbasis ICT memerlukan pemahaman, kerjasama, dan ketekunan siswa agar dapat memahami materi dengan baik.

\section{UCAPAN TERIMA KASIH}

Peneliti mengucapkan terima kasih kepada IKIP PGRI Pontianak yang telah mendanai penelitian pengembangan ini.

\section{DAFTAR PUSTAKA}

Elang Krisnadi. (2009). Rancangan Materi Pembelajaran Berbasis ICT. disajikan dalam Workshop Pengembangan Materi Pembelajaran Berbasis ICT di FMIPA UNY pada tanggal 6 Agustus 2009.

Sugiyono. (2010). MetodePenelitian Kuantitatif Kualitatif \& RND. Bandung : Alfabeta.

Sugianto, D. Abdullah,A.G. Elvyanti, G. Muladi, Y. (2013). Modul Virtual: Multimedia Flipbook Dasar Teknik Digital. INVOTEC, Volume IX, No.2: 101-116.

Trianto. (2007). Model Pembelajaran Terpadu dalam Teori dan Praktek. Jakarta: Kencana Prenata Media Grup.

Winkel W.S. (2009). Psikologi Pengajaran. Jakarta : Grasindo 